\title{
Miljövänliga arabemiraten
}

Hur världens största resursförbrukare kan upprätthålla en miljövänlig image.

Pernilla Ouis är fil.dr. i humanekologi vid Lunds universitet, samt lektor och forskare vid Internationell migration och etniska relationer, Malmö Högskola. 
TEXT: Pernilla Ouis

FÖRENADE ARABEMIRATEN har en av världens absolut största förbrukning av energi och vatten per capita i världen. Landet är en enda stor byggplats av mega-projekt och dess medborgare har en konsumtionsnivå som bara kan matchas av de allra rikaste länderna i väst. Samtidigt har landet en tydlig miljöprofil på den globala marknaden. På något sätt kan dessa motsägelsefulla fakta kombineras i den moderna miljödiskursen. Hur är det möjligt? Artikeln beskriver hur ekologisk modernisering och dess retorik kring "hållbar utveckling” effektivt döljer motsättningarna mellan miljö och ekonomi exemplifierat med utvecklingen i Förenade arabemiraten.

Tänk om ...

Föreställ er följande scenario: Ett fattigt nomadiserande folk lever i ett av världens mest extrema miljöer; oerhörd hetta och torka i ett kargt landskap. Naturen är inte grön och livgivande, utan torr, brun och ogästvänlig. Knappheten på resurser präglar hela tillvaron och som på sitt sätt uthärdas genom en stark tro på Gud och ödet. Men så plötsligt händer något: en naturtillgång hittas under ytan i detta område. Denna naturresurs visar sig vara så livsnödvändig för industrialismens framväxt att den kan sägas vara blodet i industrisamhällets ådror. Även om resursen relativt sett är underbetald får plötsligt de lokala styrande stammarna enorma rikedomar och börjar utveckla sitt land i en aldrig tidigare skådad takt. Inom loppet av några decennier har området utvecklats till en modern nationalstat med ultramodern infrastruktur med världens högsta konsumtionsnivå och bruttonationalprodukt per innevånare. Stormakternas politik kommer hädanefter att präglas av kontrollen över denna essentiella naturresurs.

Låter det som en otrolig historia? Ja, men det är faktiskt sann, för den arabiska halvöns historia (Saudiarabien och de arabiska gulfstaterna) skulle kunna beskrivas och tolkas såhär. Få länders historia kan beskrivas i termer av snabb utveckling i tid och rum från en extrem till en annan som i denna del av världen. När jag för ett antal år sedan påbörjade mitt avhandlingsarbete i humanekologi vid Lunds universitet ville jag förstå "naturumgängets modernisering" i denna unika utveckling och valde att fokusera på Förenade arabemiraten: en federation av sju små shejkdömen grundat I97I vid den arabiska sidan av Persiska viken. Följande artikel och dess huvudpoänger bygger på min avhandling i humanekologi från 2002. ${ }^{1}$ 
Olika länders konsumtion av jordens resurser kan mätas genom det så kallade "ekologiska fotavtrycket", som är en omvandling eller slags "översättning” av resurser till landyta. Förenade arabemiraten har världens största fotavtryck per capita: II.9 hektar per person jämfört med USA som har 9.6 ha/capita. Dessa siffror kan relateras till det globala medelvärdet på 2.2 ha/capita (uppgifter från 2006). ${ }^{2}$ Emiratiernas livsstil förbrukar resurser på många olika sätt. Arabemiraten är ett samhälle helt beroende av bilar, där man gärna kör stora bensinslukande fyrhjulsdrivna fordon och där kollektivtrafik saknas. Landet har en enorm konsumtion av

\section{Emiratens grönska ses som ett tecken} på en god Gud och en god ledare som skänkt sitt folk en ny grön natur.

olika varor och vatten, energikrävande luftkonditionering och stora områden med artificiell grönska för att nämna något. Bristen på naturliga, förnyelsebara vattenkällor är akut. Landet gör visserligen stora satsningar för att förbättra sin miljö, och trots att de anammat modern miljöteknologi och skärpt miljölagstiftningen går förändringen till det bättre långsam. Det är svårt att hitta exakta uppgifter kring utsläpp av olika föroreningar, men generellt kan kanske sägas att det är den stora mängden av bilar och tung fordonstrafik, utvinningen av fossila bränslen och annan energikrävande industri som skapar miljöproblemen hellre än brist på rening och god teknik. Eftersom Förenade arabemiraten anses vara ett land under utveck- ling krävs de inte heller på att begränsa sina koldioxidutsläpp enligt Kyotoprotokollet såsom andra rika länder. Denna situation kan verka paradoxal. Ekonomin bygger på försäljning av fossila bränslen, därefter turism och olika handels- och finansverksamhet som shopping och skattefria företagszoner. Landets egna medborgare är en minoritet i befolkningen, som främst består av gästarbetare från Asien.

\section{"Rulla tillbaka öknen"}

Olika fenomen i samhället kallas ofta för "sociala konstruktioner" i akademisk jargong. Med en konstruktion menas det som inte är "av Gud eller naturen givet”, och ofta innefattas också en kritik av hur någonting är när det dekonstrueras. I min teoretiska ansats $\mathrm{i}$ avhandlingen påstod jag att även naturen var en sådan "konstruktion" men i tre dimensioner: en mental dimension som handlar om värderingar och natursyn, en social dimension som handlar om de sociala relationer som möjliggör en viss natur samt en materiell dimension som manifesterar naturen rent biofysisk. De flesta av oss har lättast att se den biofysiska manifestationen av naturen - det vill säga det gröna som växer och djuren som finns däri. Vi betraktar inte naturen som något konstruerat av människan - utan rent av som motpolen till det "konstruerade" samhället och kulturen. Naturen har kommit att endast bli denna tredje dimension, men jag hävdar att de mentala och de sociala aspekterna av naturen som en konstruktion är förbisedda och minst lika fundamentala för den natur vi har. Att exemplifiera dessa tankar med Förenade arabemiratens natur i moderniseringsprocessen gör detta tydligare. I detta land har det "naturliga" torra öken- 
landskapet under decennier ersatts med växtlighet $\mathrm{i}$ en process som beskrivs med termerna "rulla tillbaka öknen" och "emiratens grönande" i den nationella retoriken. Nya djurarter har sökt sig till den nya gröna växligheten och det finns till och med de som påstår att planteringarna förändrat klimatet så att det lokalt regnar mer. Emiratens gröna och miljövänliga image poängteras alltid i officiella publikationer och uttalanden.

Vilka kulturella normer och föreställningar ("mentala konstruktioner") har varit förutsättningen för skapandet av denna nya gröna natur? För det första är idén att grön växtlighet är bättre än öken fundamental, och den uppfattningen har sin grund i den gamla beduinkulturen. Den gröna färgen har en tydlig symbolisk livgivande innebörd. "Det gröna är livet, allt som är grönt ger liv”, sa en informant under en intervju. Grönskan visar var dromedarerna kan hitta bete och ge rikligt med mjölk, som tillsammans med dadlarna varit huvudföda för beduinerna. Förenade arabemiratens första president under drygt 30 år (I97I-2004) och den moderna statens landsfader Shejk Zayed bin Sultan Al Nahyan (I9I8-2004) byggde mycket av sin politiska legitimitet på beduinkulturens värderingar. Shejk Zayed beskrivs som "ledaren som älskar grönt" och anses personligen ansvara för emiratens omfattande planteringar. Shejken beskrivs som en framsynt man med omfattande kunskap om den lokala naturen, men hur denna hårda natur även fått shejken att driva på moderniseringen, samtidigt som miljön ska skyddas till varje pris. Hans lokala förankring i öknen poängteras ofta, samtidigt som han har en modern förståelse för miljöproblematiken: "From his desert journeys, Sheikh Zayed developed an understanding of the relationship between man and his environment and, in particular, the need to ensure that sustainable use was made of natural resources." ${ }^{3}$ Han har även fått flera internationella utmärkelser för sitt miljöarbete, framförallt för arbetet mot ökenspridning även om det är diskutabelt om dessa kostsamma planteringar fyller något syfte i detta avseende. I landets officiella årsbok från 2006 publicerad av ministeriet för information och kultur sägs:

The remarkable environmental legacy left behind by the late Sheikh Zayed bin Sultan Al Nahyan continues to shape the running of the UAE [United Arab Emirates, min kommentar]. Environmental responsibility now underpins almost all relevant decision-making processes on a day-to-day basis. Sustainable development, greening of the landscape and the propagation of endangered species were special interests of a man ahead of his time. ${ }^{4}$

Natursynen grundas också på islamiska värderingar där Gud ses som den generösa skaparen av naturen för människan och Paradiset som en prunkande grön trädgård. Islams symbolfärg är också grön. Emiratens grönska ses som ett tecken på en god Gud och en god ledare som generöst skänkt sitt folk en ny grön natur.

Sociala relationer och institutioner konstituerar alltså också naturen. Den nya gröna naturen behöver ständig bevattning, gödning och andra kemiska hjälpmedel för att överleva den torra och näringsfattiga miljön. Denna tillsyn och arbetsinsats sköts av de många lågutbildade gästarbetarna, vilka utgör nästan tre fjärdedelar av befolkningen. De stora gröna projekten har 
visserligen initierats av den lokala eliten, men dess genomförande sköts av dessa immigranter. I ett marxistiskt perspektiv kan det sägas att sociala relationer manifesteras i naturen. Högutbildad expertis från utlandet behövs också för att driva alla de miljöinstitutioner som skapats på senare tid till exempel Federal Environmental Agency (grundat I993) och Environmental Research and Wildlife Development Agency (grundat I997) men som 2005 ombildades till Environment Agency - Abu Dhabi. En ny federal miljölag antogs I999. Denna lag stipulerar hårda straff för miljöbrott inklusive dödsstraff, vilket torde vara unikt i världen. Fristående miljögrupper existerar, men kan knappast kallas för

\section{"Det gröna är livet,} allt som är grönt ger liv."

NGOs utan hellre för GINGOs det vill säga "Government Inspired Non-Governmental Organizations” eftersom de skapats på initiativ av regeringen och har ett nära samarbete med det politiska etablissemanget. Miljöinstitutioner har inte sin grund i den civilisationskritiska miljörörelsen av gräsrötter som uppstod i väst under I960-talet. Miljöengagemanget är snarare ett initiativ uppifrån som stöd för modern utveckling, inte en kritik av den. Dessa institutioners verksamhet består mycket av att sprida publikationer, fira olika miljödagar och andra events samt att dela ut olika miljöpriser och andra utnämningar. Viktiga aktörer i miljödiskursen är också olika kommersiella bolag, inklusive de nationella oljebolagen. Dessa har flera gånger fått pris för sitt miljöengagemang och samarbetar med miljögrupperna. De sponsrar ofta deras publikationer och evenemang. Uppfattningen att konsumtion och ekonomiska intressen är ett hot mot miljön är helt främmande i Förenade arabemiraten. Miljöarbetet sker i en anda av smidigt samförstånd.

\section{Gröna megaprojekt}

Olika gröna megaprojekt exemplifierar den enastående omvandlingen av naturen rent biofysiskt. Emiraten har en av världens största förbrukning av vatten per capita, vilket delvis kan förklaras med all vattenåtgång för att upprätthålla all grönska. Vatten tas från fossila lager och genom avsaltning av havsvatten, vilket är en mycket energikrävande process. I de stora städerna finns fantastiska parker och planteringar med färgsprakande blommor, gräsmattor och träd där nya fågelarter häckar. På landsbygden har man gjort stora satsningar på jordbruket med stora odlingar av olika grönsaker och fruktträd. En del sorter är nya för landet, men man har också satsat på inhemska arter som visat sig överleva väl här. Dadelpalmen är den traditionella gröda man satsat mest på och man har satt hundratals miljoner dadelpalmer de senaste decennierna enligt officiella uppgifter. Dadelodlingarna upptar hundratusentals hektar land och är en nationell stolthet. Trots den stora satsningen på jordbruket importeras tre fjärdedelar av alla livsmedel till emiraten och målet om självförsörjning som framställs i den officiella retoriken är långt ifrån realistiskt. Inofficiellt påstås det att man håller på att ge upp vissa planteringar och skogar; de

Arabemiraten är ett samhälle helt beroende av bilar. 
kräver för mycket resurser och ger för litet tillbaka.

Landet har många nya naturreservat och skyddade områden. En del av dessa är "naturliga" medan andra kan verka mer konstruerade som exempelvis Shejk Zayeds ö Sir Bani Yas. Denna ö har en storlek på 220 kvadratkilometer varav 98 av dessa har kultiverats med bland annat en miljon träd av olika sorter. Ön är också ett reservat för en mängd olika djur, både inhemska arter och andra utrotningshotade djur som importerats dit. Exempel på djur på ön är giraffer, strutsar, gazeller. Skötseln av ön kräver 600 anställda och har ett eget avsaltningsverk för att producera de enorma mängder vatten som krävs för allt djur- och växtliv.

Förenade arabemiratens ekonomi grundar sig på försäljningen av fossila bränslen. Utan denna skulle hela ekonomin falla sönder. Man försöker dock diversifiera ekonomin och minska sin sårbarhet genom att satsa på andra inkomstkällor. Turismen har blivit det viktigaste inkomstalternativet till oljan. Turisterna lockas av sol och bad, lyxhotell och billiga konsumtionsvaror i ett överflöd i ett stort antal moderna shoppingcentra. Mycket av de stora förändringar av naturen vi kan se idag handlar om att öka utbudet till turisterna och öka emiratens attraktionskraft på den globala turistmarknaden. Vintersporter erbjuds till och med: ishallar för skridskoåkning och en slalombacke inomhus med konstgjord snö i ett av världens absolut varmaste klimat. Turister erbjuds också dykning, vattenskidåkning och bad i havet, spela golf på stora gröna golfbanor, att köra fyrhjulsdrivet i sanddynerna och annan "off-road" körning i den emiratiska naturen för att nämna några populära aktiviteter.
Den senaste stora turistsatsningen är de tre stora artificiella så kallade palm-öarna, som fortfarande är under konstruktion och kallas "världens åttonde underverk" på dess officiella hemsida. Öarna har vardera formen av en palm och har initierats som en lösning på problemet med bristen på tillgängliga stränder för turisterna. Hotell och andra turistanläggningar byggs på öarna. Projektet beskrivs som positivt ur en miljösynpunkt eftersom miljöutredningar och övervakningar implementerats, miljövänliga material och teknik används, att nya ekosystem skapats samt att ekologer har övervakat processen. Att tusentals nya turister kommer att öka växthusgaserna avsevärt med sina flygtransporter och luftkonditionering samt all vatten- och annan resursförbrukning som tär på landet nämns inte. Dessutom har själva skapandet av öarna krävt enorma resurser och transporter som knappast kan vara förenliga med en hållbar utveckling.

\section{Miljöumgängets modernisering}

Hur vi människor förhåller sig till naturen och "umgås" med den ändras över tid. Hur vi tänker om naturen och hur vi använder den är föränderligt och är direkt sammanlänkad med mänsklig försörjningsstrategi. Beduinerna levde i naturen på ett helt annat sätt än dagens emiratier behöver göra. Beduinerna var kända för sin skickliga överlevnadsförmåga i den krävande miljön. Befolkningen i nuvarande arabemiraten var inte uteslutande nomadiserande dromedaruppfödare utan hade en mycket diversifierad försörjningsstrategi. De levde visserligen av sina dromedarer och mjölken dessa gav samt de pengar de kunde få från karavantransporter, men de var också beroende av odlingar av fram96 
förallt dadlar vid oaserna. Havet var en viktig näringskälla där fiske och dykning efter pärlor var central i ekonomin. Fram till I930-talets slut var faktiskt pärlfisket befolkningens viktigaste inkomstkälla. Efter depressionen och införandet av odlade pärlor kollapsade denna verksamhet snabbt. Dromedarerna kunde också utfodras med fisk och de fick ibland simma ut till öarna och beta där.

När landet moderniserades upphörde mycket av de traditionella näringarna. Beduinerna blev bofasta och kunde njuta av den nya moderna välfärdstatens generösa skyddssytem för sin försörjning. Många blev arbetslösa utan att deras privatekonomi blev lidande. Antalet dromedarer minskade drastiskt under I970-talet vilket fick de styrande att reagera. Kapplöpningstävlingar för dromedarer infördes och formaliserades i gulfstaterna och Saudiarabien under denna tid för att motivera befolkningen att fortsätta föda upp dromedarer. Man kan tänka sig att den snabba livsstilsförändringen följdes av nostalgi och ett förändrat förhållningssätt till naturen. Jag har teoretiserat denna förändring i termer av en ökande reflexivitet.

I förmoderna kulturer saknas ofta ett ord för natur, så även i arabiskan. Det är inte "naturen" som abstraktion som man refererar till, utan till konkreta naturfenomen och platser i närmiljön. I traditionell arabisk beduinpoesi omtalas naturfenomen, men aldrig i termer av "natur". En första reflexivitetsnivå i moderniseringen uppnås när man inte längre lever $\mathrm{i}$ naturen, utan distanserat sig från den som något utanför den egna livsvärlden. När naturen blivit något externt och inte längre är en oreflekterad del av livet brukar ett ord för "natur" uppstå. Jag kallar detta för primär reflexivitet i moderniseringens tidigaste fas, och denna har i västerländsk historia främst formulerats i den kartesianska dualismen. Primär reflexivitet uppstår i övergången från ett traditionellt till ett modernt samhälle.

En sekundär reflexivitet, menar jag, uppstår i moderniseringens senare skede när man inser att den nya distanseringen och alienationen inför naturen är problematisk eftersom miljöproblem har skapats av den nya livsstilen. Naturen blir ett objekt som ska räddas från människan och benämns ofta med det nya begreppet "miljö". Miljön blir utsatt för naturvetenskapens kritiska

Lagen stipulerar hårda straff för miljöbrott, inklusive dödsstraff, vilket torde vara unikt $i$ världen.

blick; hur mycket påfrestningar tål den, var går gränsen? Miljön måste mätas, observeras och undersökas. Reflexiviteten institutionaliseras i en utvecklad modernitet och det är detta vi kan se exempel på i Förenade arabemiraten. ${ }^{5}$ Parallellt med utvecklingen av miljön som ett objekt för vetenskap och management, blir naturen ett konsumtionsobjekt. Den förmoderna relationen till naturen karaktäriseras av kravet på överlevnad. I ett modern utvecklat land blir naturen en plats man besöker, upplever och konsumerar. Att den är ren, vacker och orörd är ett konsumentintresse, inte en förutsättning för överlevnad som i det förmoderna. I emiraten är inte den traditionella naturen intressant längre, utan den moderna, gröna, av människan skapade naturen. Det är den som väcker stolt- 
het och den som man vill se i sitt land och besöka - det är den som konsumeras. Hur omsorgen om miljön har utvecklats och institutionaliserats i det moderna samhället har dock sin egen historia värd att titta närmare på.

\section{En ny diskurs: Ekologisk modernisering}

Den miljörörelse som växte fram i väst under i960- och 70-talet betraktade modernisering och ekonomisk tillväxt som orsaken till utarmningen av jordens resurser och miljöförstöringen. Rörelsen var starkt moralisk och civilisationskritisk mot vetenskap, industrialism, kapitalism och materialism för att nämna några exempel. Analytiker av miljörörelsen menar att under slutet av I980-talet ändrades denna inställning i grunden. Milstolpe i den nya miljödiskursen, den så kallade ekologiska moderniseringen, och det paradigmskifte som följde var den så kallade Brundtlandrapporten "Vår gemensamma framtid" publicerad i987 av World Commission for Environment and Development. En annan milstolpe var United Nations Conference on Environment and Development i Rio de Janeiro I992 som visade att denna diskurs snabbt hade blivit etablerad. ${ }^{6}$

Det nya i diskursen kan kortfattat förklaras såhär: Miljö- och ekonomiska intressen sågs tidigare som varandras motpoler, men nu sågs istället möjligheter till en win-win-situation: En bra ekonomi var bra för miljön, samtidigt som en sund miljö sågs som en förutsättning för en stark ekonomi. Den så tidigare kritiserade moderniseringen sågs inte som orsaken till miljöproblemen, utan istället som lösningen till den: Ekonomisk tillväxt, bättre teknik och modern resursanvändning skulle lösa problemen; man skulle mod- ernisera sig ur miljökrisen, därav termen "ekologisk modernisering". Sociologen Klaus Eder förklarar situationen i termer av att miljörörelsen hade utgjort ett hot mot det moderna projektet, men att moderniteten "vann" och ekologi blev modernitetens nya "masterframe". ${ }^{7}$ Miljörörelsen hade tidigare pratat utanför de etablerade maktstrukturerna, men nu växte en diskurskoalition fram mellan olika aktörer. Det nya begreppet "hållbar utveckling" som marknadsfördes hårt i Brundtlandrapporten förde samman aktörer från alla sfärer i samhället. Begreppet är vagt, brett och öppet, men har sin styrka i att just dessa egenskaper möjliggör för olika aktörer att själva tolka in vad det står för. Kritiker har dock menat att begreppet "hållbar utveckling” möjliggör att man hellre värnar om den ekonomiska utvecklingens bevarande och hållbarhet än om miljöns. Begreppet blev i deras syn utnyttjat som ett försvar av ekonomisk utveckling och tillväxt.

Rio-mötet 1992 markerade att nu var världens samlade krafter eniga om att rädda världen: politiker, företrädare för kommersiella intressen, NGOs med flera. Det är denna konsensus som vi kan finna $i$ Förenade arabemiratens diskurs: alla är överens och strävar åt samma håll. De antog den ekologiska moderniseringsdiskursen rakt av under I990-talets början. Så vad är då problemet? Det som är problematiskt, menar jag, är att ekologisk modernisering döljer och mystifierar motsättningarna mellan ekonomi och miljö - det som den tidiga miljörörelsen pekade på. Det är problematiskt när ett land med den oerhörda resursförbrukning som Förenade arabemiraten har, kan framställa sig själva som miljövänliga. Jag anser att det är fel att locka tusentals turister till ett så sårbart 
område. Det är i mitt tycke inte bra om konsumenter inte öppet kan få del av kopplingen mellan den privata konsumtionen och miljöpåverkan. Den europeiska miljörörelsens slogan som lyder "Den bästa miljövänliga varan är den som du inte köper" har inte fått fotfäste här. I en alltför hårt driven konsensus har en kritisk röst svårt att bli hörd. Arabemiraten har importerat den nya miljödiskursen helt och hållet och synen att miljöfrågan skall lösas inom de etablerade ekonomiska och politiska strukturerna. Även om arabemiraten kan köpa sig den bästa miljötekniken och expertisen, är dess ekonomiska utveckling i grunden ekologiskt ohållbar. Precis som den i väst, måste då tilläggas. För vilka är vi att moralisera? Vi som köper deras olja och i utbyte gärna exporterar konsumtionsvaror till dem och turistar i dess sol.

En slutlig metareflektion kan vara att Förenade arabemiraten är ett pedagogiskt tydligt exempel på konstruerandet av naturen och mystifieringen förknippade med ekologisk modernisering. Vår egen naturkonstruktion hemma har vi svårare att få grepp om. En mycket stor del av EUs budget går åt till att upprätthålla Europas jordbruk, en verksamhet som inte kan bära sig själv ekonomiskt och som inte med den bästa viljan i världen kan kallas för ekologisk. Varför tycker vi jordbruket gjort sig förtjänt av så stora resurser och så lite kritik? Mitt svar på den frågan är att vi hellre vill ha öppna landskap än skog, och vi är beredda att betala ett högt pris för det. Korna i Sverige hålls inte längre för kött och mjölk, utan endast som landskapsvårdare och genererare av EU-bidrag till bönderna. Det är den natur vi vill konstruera här. Det är förvisso lätt att kritisera "den Andre” som exempelvis denna genomgång av resurskrävande gröna projekt i arabemiraten och hur olja byts mot grönska, men det är betydligt svårare att se sin egen situation. Naturens sociala och mentala konstruktion verkar vara omöjligt att genomskåda för gemene man oavsett kontext.

\section{- $f \cdot$}

I Ouis, Pernilla : "Power, Person, and Place: Tradition, Modernity, and Environment in the United Arab Emirates". Lund: Lund Studies in Human Ecology, 2002.

2 Uppgifter från WWF publicerade på Sustainable Foot prints hemsida http://www.sustainablefootprint.org/ en/cms/gebruikerscherm.asp?itemId=38I (2207-09-06)

3 Citat från hyllningsskriften "Sheikh Zayed bin Sultan Al Nahyan - A special tribute" (författare ej angivet), sid Io, nedladdningsbar från UAE Interact (Supported by The National Media Council) on www.uaeinteract.com (2007o9-06).

4 UAE Ministry of Information and Culture, "United Arab Emirates Yearbook 2006”, Trident Press Ltd, sid 287.

5 Primär och sekundär reflexivitet är mina termer, men man kan läsa om miljö, reflexivitet och modernitet i följande källor: Beck: "Risk Society: Towards a New Modernity". London: Sage, I992. Lash \& Urry: "Economies of Signs and Space”. London: Sage, I994. Macnaghten \& Urry: “Contested Natures”. London: Sage, I998.

6 Hajer, Maarten: “The Politics of Environmental Discourse: Ecological Modernization and the Policy Process". Oxford: Claredon Press, I995.

7 Eder, Klaus: “The Social Construction of Nature”. London: Sage, 1996. För ytterligare utveckling och referenser kring ekologisk modernisering i Förenade arabemiraten se kapitel 9 "Modernizing Nature, Naturalizing Modernity" i min avhandling. 